PROBLEMS

OF MANAGEMENT IN THE $21^{\text {st }}$ CENTURY Vol. 12 , No. 1, 2017

54

\section{IDENTIFICATION OF RELATION BETWEEN BUSINESS MODEL AND BUSINESS STRATEGY AND MEASUREMENT OF ITS TIGHTNESS}

\author{
Štefan Slávik, Robert Hanák \\ University of Economics in Bratislava, Slovakia \\ E-mail: stefan.slavik@euba.sk, robert.hanak@euba.sk
}

\begin{abstract}
Business model and business strategy fundamentally characterize and predetermine the essence of a company and its action. Research has already brought a fairly extensive knowledge of the model and strategy too. There is also emerging evidence that describes the relationship between model and strategy, but it is not verified by empirical research. The research confirmed the existence of a real relation between model and strategy using quantitative methods. Business model impacts significantly on the market position of the company, has got implications for competitive advantage, originality/uniqueness of the company action and of its passivity/activity. The acquired knowledge can be used to purposeful alignment of model and strategy. A higher degree of intensity of this relationship improves the market position of the company and may be a potential source of higher company performance.
\end{abstract}

Keywords: business model, business strategy, model-strategy-relation, market position.

\title{
Introduction
}

Survival and successful progress of the company must meet a number of conditions with varying degree of importance and urgency. Business model and business strategy fundamentally and significantly shape the company and its action. The business model solves the existential condition, thus how a company will make money, the business strategy solves the condition of a further progress, therefore how a company will act in a competitive environment. Research of the internal consistency of the model and the strategy and explanation of the relation between the business model and strategy may bring new knowledge on the causes and conditions for successful existence and progress of the company.

\section{The Current State of Knowledge on the Relation between Business Strategy and Business Model}

Knowledge on the tightness and degree of dependence between the business model and business strategy enables to confirm an existence of the link between two relevant terms of viability and business success of the company. Knowing and respecting the degree of dependence has a considerable impact on the content of model and strategy. Less dependence between model and strategy can appear in different length of their life cycle, in varying adaptability to external and internal conditions within which company operates, in a smaller penetration of joint elements, in the different role they play in the origin and sustaining of competitive advantage and in smaller demands on coordination of their content and implementation. Greater dependence does not mean a greater affinity of content, rather it will be a closer relationship mutually complementing, though, different elements and units. Greater dependence between the model and strategy is reflected in the improved compliance of their life cycles, in approximately the 
Štefan SLÁVIK, Robert HANÁK. Identification of relation between business model and business strategy and measurement of its tightness

\author{
PROBLEMS \\ OF MANAGEMENT \\ IN THE $21^{\text {st }}$ CENTURY \\ Vol. 12, No. 1, 2017
}

same adaptability to internal and external changes, in a greater penetration of joint elements and sources of competitive advantage and greater requirements for maintenance of their functional compliance.

The traditional textbook definitions consider a strategy mostly as comprehensive or main plan, which is used to achieve the objectives of the company. Thus, the strategy is seen by Ch. W. L. Hill and R. G. Jones (2007, p. 3), T. L. Hunger and J. D. Wheelen (2008, p. 14), M. Keřkovský and O. Vykypěl (2003, p. 7), A. A. Thompson, A. J. Strickland and J. E. Gamble (2007, p. 3, 4), R. Grant (2008, p. 12). They are associated by their joint notion about a strategy as a plan to achieve the objective, the plan is emphasized as a way of achieving the goals, the plan is the core strategy and the major policy question. The objectives are achieved through key, critical and therefore strategic ways. The weakness of these definitions is a general description of the strategy, which does not provide notion of the content of the strategy in practical terms. A. Karnani (2008, pp. $28-34)$ tries to capture the essence of the strategy that he deems it as a set of interrelated decisions about the industry in which the company will compete, the sources of its competitive advantage, benefit, which offers its customers and organizational arrangement needed to implement the strategy. C. Markides (2008, pp. 65 - 73) concludes to the opinion that the strategy resides in identification of target customers, products and services, how to offer these products and services to target customers. G. Hamel and C. K. Prahalad (1996) to the contrary emphasize that the essence of good strategy is to create new markets, new products, new industries and new "white spaces". D. J. Collis and M. G. Rukstad (2008, pp. 82 - 90) consider well defined strategy if it contains three critical components which are a goal, scope (area, branch, field of activity) and advantage. J. Magretta (2002) although primarily addressed the topic of business models, but in addition aptly demonstrated on the same base, on the same business model different strategies can grow up that are (should be) unique in the following components: market, position, technology, product, services, customers. D. C. Hambrick and J. W. Frederickson (2001, pp. 48 - 59) are doing in the determination of good strategy relatively straightforward and suggest that it has five parts:

1. The activity scope: Where will we be active?

2. The way: How will we get there?

3. The difference: How will we win in the market?

4. Procedure: What will our speed and sequence of steps be?

5. The economic logic: How will we get our revenues?

Unlike previous definitions of strategies there are emerging dynamic elements of the company action too and explicit asking serious questions what will be economic impact of strategy formulated in such a manner.

Penetration of the quoted characteristics of the strategy can be summed up in questions answers of which should adequately reflect the content of the strategy:

- Where? In what industry, in which segment, in which territory, in which position does the company operate?

- Who? Who is the customer?

- What? What are the needs, what products and services meet customer needs? What benefit is provided to the customer?

- How? What way are products and services created and sold, on what technologies are they based, in what organizational arrangement do they work, in what does their uniqueness reside?

As it is clear from the literature review, there are so many features of the strategy as is number of their authors. Probably it does not make sense to create further definition in shape of penetration of previous characteristics. However, there are some obvious resemblances in the entire package of definitions that enable to identify a several characteristics of strategy that mutually create while eclectic, but comprehensive and perhaps even a holistic characteristic of strategy: 
Štefan SLÁVIK, Robert HANÁK. Identification of relation between business model and business strategy and measurement of its tightness

PROBLEMS

OF MANAGEMENT

IN THE $21^{\text {st }}$ CENTURY

Vol. 12, No. 1, 2017

1. The strategy is a method and an instrument for achieving the objectives. It is a major plan of company or action plan. Developing and strengthening competitive advantage is often regarded as a key means for achieving the objectives.

2. The strategy is a set of specific decisions about to meet the needs, products, customers, markets, resources, technologies, key strategic processes and other relevant objects. Their individual quality, expensiveness and interconnectedness create competitive advantage.

3. The strategy is an attitude (starting position predetermining action), which can be:

- competitive: aggressive, offensive, defensive, cautious, shy,

- initiative: pioneering, monitoring/adaptation, waiting, pre-active, reactive, passive,

- conscious: purposeful, opportunistic, imposed, spontaneous, chaotic and the like.

4. The strategy is an action that has some degree of dynamism, originality, diversity, ingenuity, consistency, clarity, adaptation, responsiveness, ambition and the like.

5. The strategy is a measure of things and events that are great, main, principal, critical, unrepeatable, surprising, fateful, long-term and the like.

Business strategy responds to the fundamental and fateful questions that each company should ask: Who are we? Where are we placed? Where do we want to get? Where should we get? and in particular: How do we get there? It seems that there is no more fundamental question for the company's survival. However, it may be asked more ruminative question of what lies behind the strategy, what is more important and more essential for the company than its business strategy. It turns out that under the strategy there is a business system or set of processes and resources which in a coordinated cooperation create products or services that satisfy customer needs. For this entrepreneurial system there is established a label of business model that answers the company elementary question: "How to increase the value of expended resources, how to make money?" It is clear that without a satisfactory answer to this question asking concerning the strategy does not make sense.

Although the concept of business model became a prominence of attention of academics and practitioners recently only, it was part of the expression of businessmen a longer time yet and its beginnings can already be found in the works of Peter Drucker. Despite the increasing body of literature on this topic there is not a consensus in defining it. J. Magretta (2002) considers the business model in its very essence as a story that explains how the company works. A. Afuah $(2004$, p. 2) perceives the business model similarly, he considers the business model for the system to make money. It includes a set of activities that a company executes in some way and at some time in order to offer its customers benefits, what they want, and make a profit doing so. M. Johnson, C. Christensen, and H. Kagerman (2008) do not strive for a very explicit definition of the business model, but they hold an opinion that every successful company operates according to an efficient business model. If there are systematically identified its basic parts, so the top managers understand how the model solves (offers) meeting the needs on a profitable basis, in the process it uses key resources and key processes. According to D. Teece (2010, p. 173), business model expresses the logic and provides data and other evidences which demonstrate how the business develops and provides value (benefit) to the customer. It also depicts the structure of revenues, costs and profits associated with the way the company provides this value. Ch. Zott and R. Amit (2010) bring a broader view of the business model, they shape the concept of the business model as a system of interrelated activities that go beyond company boundaries. The system of activities allow in concert with partners to create value and also appropriates a portion of this value. D. Benoit and X. Lecocq (2010), more generally, see the business model as a concept that describes the relationships between its various components, which are a precondition to create value for customers and the company itself. R. Casadesus-Masanell and J. E. Ricart (2011) very differently and even individually approach to defining business model. Based on research study they suggest that one component of the business model are the decisions taken by executives on how the organization should be operated and the second component are their consequences. In the simplest conceptualisation therefore business model consists of a set of managerial decisions and the consequences of those decisions. 
In most definitions of models, three separate elements will emerge. These are products or services offered to customers, the way the company is organized to deliver these products and services to customers, and the way how to appropriate a part of the produced value, thus the profitable and/or revenue model. Definitions differ then in emphasis on these elements. The business model is simply a machine for making money, but money is important not only to earn but also to appropriate it. The business model depicts the company as a place of decisions and their consequences too, as a set of resources and activities in varying degree of detail which in interaction shape the value (benefit) for the customer. The business model may be limited when it is localized to the enterprise, or open, when the partners are too incorporated. Economic concept of model places emphasis on business economics, it is a narrow view. Systemic or a conceptual approach emphasizes again the overall functioning of the company, including resources, processes and benefits for the customer, and therefore it is a broader view of the business model.

Visualization business model is the way how to depict the operation of the business. Almost all visualizations use the resources and activities of the company for a description. Processual side is perhaps more significant in the model of Teece (2010, p.173), who does not describe closer how the company's resources operate. Casadesus Masanell and Ricart (2011) originally approach to making model they use a set of decisions and their consequences to display, but these decisions and consequences still ultimately relate resources and processes. The advantage of this methodology is vital managerial approach because the decision making brings into model making adaptation, dynamism, innovation and development. Special attention deserves model Canvas by Osterwalder and Pigneur (2009, pp. 15-44) that resembles a painting canvas because of its figure contains nine blocks that allow "paint" pictures of new or existing business models. Drawn on a large surface is an inspiring space for sketching and discussion about the elements of the business model.

At the beginning of the examination of the relation between model and strategy there is necessary to assess reasonableness of the question: What is the first one, what is the basis and what is the second one, or derived, what is the superstructure, or what is general and what is specific? Meaningfulness of such a question stands out when academic puts himself in the position of the entrepreneur. Businessman looks for unmet need or creates a completely new need, proposes a way to satisfy it and tries satisfying the need to monetize. While he does not figure out how to make money with a profit, possibly with a repeated procedure which is basically the same as the business model, there is no sense to develop a strategy. This is best seen in start-ups, which solve the functionality of the business model in the early stages of its existence and begin to think about a strategy in the final stages of their development when they enter the market and meet the competition. Formulation of a strategy for a company that does not make money in the consequence of a dysfunctional model does not make any sense. In the centre of the business model there lies the answer of the question to "How to make money?" The answer to the question "Where to place a model, how and where to use it?" is again at the centre of business strategy. The model in this respect is the foundation on which strategy grows. For a company, the model is a phenomenon that has fundamental, existential, and therefore strategic importance. When using a strategic point of view, thus what is the most important for the existence and prosperity of the company, so strategy and business model belong into strategic considerations and strategic management. Such reasoning, however, does not qualify strategy for mastering or determining position against the model or vice versa.

J. Magretta writes (2011, p. 69): “The business model and strategy are two different things. One thing explains who your customers are and how you plan to make money when you provide value with them, other thing how you beat the competition when you will be different." She adds further (2011, p. 79): "Business models describe as elements of the business fit together systematically. They do not take into account one critical dimension of performance, which is competition. Sooner or later, usually sooner, every company runs into competitors. To deal with this reality is a matter of strategy." F. Newth formulates these ideas in a similar

PROBLEMS

OF MANAGEMENT

IN THE $21^{\text {st }}$ CENTURY

Vol. 12 , No. 1, 2017

57 
Štefan SLÁVIK, Robert HANÁK. Identification of relation between business model and business strategy and measurement of its tightness

PROBLEMS

OF MANAGEMENT

IN THE $21^{\text {st }}$ CENTURY Vol. 12 , No. 1, 2017

58

way (2012, Abstract): "The business model is about how a company works and strategy is about how a company competes." She further explains $(2012$, p. 2): "The business model is an internal system that is composed of elements, links and dynamics, while the strategy is an external competitive approach using competences that have developed in the business model." The relationship model and strategy is becoming clearer on the base of assertion (2012, p. 90): "Looking at the strategy from the point of view of business model makes it more concrete, because it specifies that the business model is the foundation to deliver strategy." F. Newth concludes analysis of the relationship between strategy and model (2012, p. 92): "Strategies supplement a business model that helps to decide which strategic option is the best one for the company. Competitive strategy and performance increase when business models and strategies are complementary." D. J. Teece sees the relationship between model and strategy as follows (2010): "The business model is more generic than business strategy. The choice of business strategy is more complex task than the draft of business model." From quoted opinions of Magretta, Newth and Teece follow that strategies and models are relatively independent entities but interrelated and complementary.

R. Masanell Casadesus, R. and J. E. Ricart write (2010): "The business model is a reflection of the implemented strategy. Strategy is contingent plan how to use business model." The business model is, according to their perception, a part of a wider outlined strategy, strategy shapes a model as a system of activities, strategy selects an appropriate model and prescribes some rules for its use. They see another link between strategy and model, that (2011) "whereas every company has a business model, not every company has a strategy, thus a plan of action against any emergency that may arise." It can be reasonably assumed that a company as well, which has not a planned, formal strategy, acts and this action has got a certain logic, respectively some pattern that can be considered as a strategy, and thus as a use of a model. Masanell Casadesus and Ricart state an apt analogy of relationships between strategy and model (2011): "The strategy is a design and production of a car, the business model is a car and tactics are modes of driving." This analogy may be more accurately modified in the sense that a car is the business model, the strategy is a way and place of its use and tactics are methods of driving without changing the model and strategy.

J. Muehlhausen is of the opinion that (2013, p. 19) "business model is a part of business strategy and justifies it with the fact that the business model is what you do and the strategy and tactics are how you do it." The argument about what is a part of what is inconclusive, but the separation of model from strategy is obvious.

C. M. DaSilva and P. Trkman consider (2014) "business model as a reflection of business strategy and they argue that the strategy shapes the development of capabilities that may change in the future the current business models." Practice shows however that models emerge usually non-strategic, unplanned way, as a result of many trials and errors.

More light on the relationship between model and strategy brings the knowledge that (Dos Santos et al., 2015, p. 44) "companies often compete with the same product, which is offered in the same target market segments, but with different business models. For example, GAP, ZARA and H\&M are competing in the same market products, but each with a completely different business model." It is believed that the same strategies are implemented with different models. But there is an opposite example, when companies with the same model have different strategies, for example supermarket model is used by both American Wal-Mart and Kmarkt, but with a completely different strategy. Wal-Mart operates in the American countryside and offers branded products at lower prices, Kmarkt is established in big cities and offers products at prices higher than the W-M. German retail chains Billa and Lidl are also using supermarket model, but Billa has got a much wider assortment and higher prices than Lidl and other customers too in considerable rate.

From quoted opinions of Masanell Casadesus, Ricart, Muehlhausen, DaSilva and Trkman follow that the strategy and model are linked entities, the strategy determines the model that there is a priority of strategy over model. Many uncertainties in relationship between business 
strategy and business model comes from the proximity of these two related but separate phenomena. N. Stieglitz and N. J. Foss therefore merely state (2015, p. 106): "Sometimes business models are seen as subordinate and sometimes as a superordinate to business strategy."

A reading of the literature shows that clear opinions are not about the priority of the relationship between models and strategies. This argument can be given in the favour of priority or basal position of model. The model solves the basic and existential matter of the company, which is: How to make money? This question is fateful and strategic, but the answer to it does not explain the content of the strategy. The correct answer, however, is the reason and basis for strategy formulation. To formulate a strategy for a model, that does not make money, is evident nonsense. The opposite views appear, however, that the strategy creates some preconditions in the long term that may affect the business model. Argumentation, however, does not go into depth and empirical evidences lack. Across the literature more consistent views appear that there is a dependence between the strategy and model, although again empirical evidences lack. If the model and strategy will be structured in the partial blocks, so exploration on the softer resolving level may bring new knowledge on their links. Therefore, research was conducted which ought to confirm the relationship between strategy and model, to quantify its tightness and degree of dependence. Compliance of model and strategy expressed by tightness and degree of dependence should bring increased resilience of company in a competitive environment.

\section{Methodology of Research}

The aim of empirical research is to clarify the relation between business strategy and business model. To ascertain internal dependences inside the business model and business strategy. To ponder on the meaning of homogeneity of model and strategy. To find out how tight is the connection between business strategy and business model. The tightness of dependence has got practical implications. Tight relation may reduce variability between model and strategy. Looser dependence gives more space to the independent adaptability of the model and strategy as well.

\section{Sample}

The original research sample included 231 companies willing to provide with basic data, including 80 enterprises $(34.6 \%)$ were companies from the service industry. Thirty service companies were selected for the narrowed research sample. Service companies came from subindustries: personnel agencies (8), marketing agencies (7), consulting agencies (8), law firms (3), financing agencies (4). The selected companies are typical representatives of companies from the respective sub-industries that are nominated in the survey sample. The selection criterion was the formal and content quality of information on the surveyed companies and attributes of business models that differentiated them from other models. Field research has been carried out in declining 2015 year. Every company in the narrowed research sample has been studied and described on base of individual, face-to-face managed interview. Companies are located in the city of Bratislava and its surroundings. This area is regarded as the most developed business area of Slovakia.

\section{Variables}

The business model is described by means of canvas visualization containing nine blocks. There is evaluated the originality, complexity, diversity, excellence, innovation of a parameter compared to the standard business practice in the service industry on the scale 1 (match), 2 (small gap), 3 (average difference), 4 (big difference), 5 (full difference). The blocks are characterized by 11 parameters, respectively variables:

1. Customer value proposition 
Štefan SLÁVIK, Robert HANÁK. Identification of relation between business model and business strategy and measurement of its tightness

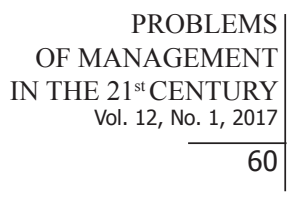

2. Customer segments

3. Distribution channels

4. Customer relations

5. Key sources - sources (evidential)

6. Key resources - capabilities (virtual)

7. Key activities - primary

8. Key actions - supporting

9. Key partners

10. Cost structure

11. Revenue streams

The business model is expressed, respectively quantified as the sum of 11 evaluated parameters, which are measured at 5 point Likert scale. Therefore minimum score is $11(11 \times 1)$ and the maximum 55 (11x5). It can be said that companies that have achieved 11 points are entirely consistent with the industry average, 22 represents a small difference, 33 a bigger difference, 44 a big difference and 55 meaning a complete difference.

The business strategy is described through eighteen parameters respectively, variables. Each parameter is evaluated according to the same scale $(1-5)$ as a business model and there is evaluated the difference rate of a parameter compared to the standard business practice.

1. Target orientation of a company: vision, mission, goals.

2. The external environment of enterprise: dynamics and complexity of the business environment.

3. The external environment of the enterprise: competitive conditions in the industry (intensity of competition).

4. Anticipating the future development of the external business environment: a level of knowledge of the future.

5. Quality of the internal environment of enterprise: competitive advantage and its sustainability.

6. The content of the strategy, the strategy as a set of concrete factual parameters: satisfied need (originality, novelty of a need)

7. The content of the strategy, the strategy as a set of concrete factual parameters: technology

8. Strategy as an instrument of competition: comparison with competitors according to rate of difference

9. Strategy as an instrument of competition: market position

10. The strategy as a way of doing enterprise: dynamics and speed

11. The strategy as a way of company action: originality and uniqueness

12. The strategy as a way of company action: clear focus (unambiguity, specificity)

13. The strategy as a way of company action: foresight

14. The strategy as a way of company action: sensitivity and awareness

15. The strategy as a way of company action: ambition

16. Strategy as an attitude of company: passivity $\leftrightarrow$ activity

17. Strategy as an attitude of company: defence $\leftrightarrow$ attack

18. Strategy as an attitude of company: modesty $\leftrightarrow$ courage

19. Strategy as an attitude of company: coincidence $\leftrightarrow$ plan

The strategy as a set of concrete factual parameters may be further described by the product (customer value proposition), customer (customer segments), resources (key resources and capabilities) and processes (key activities). These parameters, however, contain the business model, and are therefore excluded from the description of the strategy.

Business strategy is expressed, respectively quantified as the sum of 18 evaluated parameters. Minimum score is 18 and the maximum 90. It can be said that companies that have achieved 18 points are entirely consistent with the industry average and 90 points means a 
Štefan SLÁVIK, Robert HANÁK. Identification of relation between business model and business strategy and measurement of its tightness

PROBLEMS

OF MANAGEMENT

IN THE $21^{\text {st }}$ CENTURY

Vol. 12, No. 1, 2017

complete dissimilarity. The values of parameters of model and strategy are indirectly measured as a distance or positive difference from standard business practice. The higher the value of the measured parameter, the more the company positively differs from the usual practice. Model and strategy of such a company are then considered more different, more original and quality.

\section{Data Analysis}

To test internal consistency of the business model and the strategy there is used the Cronbach's alpha coefficient. Measuring internal relationship between specific model's parameters and the strategy's parameters was provided by correlation design, and because of not normal distribution, Kendall's tau b was used. Total score of the business model was used as a predictor in the regression analysis where strategy total score was the dependent variable. There was also tested total score of business model, as a predictor for every parameter in the strategy.

\section{Results of Research}

\section{Consistency of Business Model}

Cronbach's alpha $\alpha=.718$ was used to measure internal consistency of studied business models, which indicates acceptable level. Kendall's $\tau$ b was used to measure relation between specific parameters of business model which were not normally distributed. The results are quoted in table 1 . As described in section of methods, the higher score of every parameter, the more different a company is in comparison with a common business practice in an industry. Results recorded in the table 1 can be summed into these statements.

Key activities (primary and supportive), key resources (resources and capabilities) and key partnerships are closely related together which indicate that if a business model of a company is based on different blocks compared to common business practice in industry, in key activities (primary and supportive), it is also different in key resources (resources and capabilities).

Key sources closely link to the value proposition, capabilities, operations (primary and supportive) and partners. They show the most contexts (5) and it encourages one to think that they could be considered as a basis or a major determinant of the business model. Model probably arises from the fact that the founders have a certain quality and quantity of resources, including intangibles and intellectual and they seek for them an application, utilization and valorization.

Distinct and original customer segments are closely related with different relationships with customers, different distribution channels and different revenue streams. Also offering a different value for customers compared to competition is closely related with possession of the different key resources (resources and capabilities).

The criterion of success of the model are revenue streams, but which show relatively little tight links. Revenue streams are closely related to the distribution channels and customer relationships.

Based on the assumption that the emergence of a model (the start) is based on the consideration of customer value and its working is confirmed by the revenue streams (the end), so the value proposition is closely related with the resources and capabilities, resources play an important role inside the model and revenue streams naturally depend on distribution and customers. These three entities that are (1) customer value proposition, (2) resources and processes, (3) the revenue streams, however, they are mutually not too much dependent. 
Štefan SLÁVIK, Robert HANÁK. Identification of relation between business model and business strategy and measurement of its tightness

PROBLEMS OF MANAGEMENT IN THE $21^{\text {st }}$ CENTURY Vol. 12 , No. 1, 2017

Table 1. Relation of business model parameters measured by Kendall's tau b.

\begin{tabular}{|c|c|c|c|c|c|c|c|c|c|c|c|c|c|}
\hline $\begin{array}{l}\text { Blocks of business } \\
\text { model }\end{array}$ & Mean & SD & 1. & 2. & 3. & 4. & 5. & 6. & 7. & 8. & 9. & 10. & 11. \\
\hline 1. Value proposition (2) & 3.68 & .31 & 1 & -.21 & .04 & -.20 & $.41^{* *}$ & $.35^{*}$ & .22 & .22 & -.14 & -.08 & .05 \\
\hline $\begin{array}{l}\text { 2. Customer segments } \\
\text { (1) }\end{array}$ & 1.42 & .81 & & 1 & $.48^{* *}$ & .18 & .21 & .20 & .21 & .04 & .32 & .08 & .05 \\
\hline $\begin{array}{l}\text { 3. Distribution channels } \\
\text { (2) }\end{array}$ & 1.13 & .49 & & & 1 & -.007 & .19 & .26 & .16 & .03 & .3 & .13 & $.38^{*}$ \\
\hline $\begin{array}{l}\text { 4. Relationships with } \\
\text { customers (1) }\end{array}$ & 1.35 & .53 & & & & 1 & -.05 & .05 & .04 & .11 & -.13 & .264 & $.39^{*}$ \\
\hline $\begin{array}{l}\text { 5. Key resources - } \\
\text { resources (5) }\end{array}$ & 3.51 & .86 & & & & & 1 & $.6^{* *}$ & $.38^{* *}$ & $.44^{*}$ & $.32^{*}$ & .02 & .09 \\
\hline $\begin{array}{l}\text { 6. Key resources - capa- } \\
\text { bilities (3) }\end{array}$ & 3.75 & .63 & & & & & & 1 & .23 & $.36^{* *}$ & .26 & .08 & .19 \\
\hline $\begin{array}{l}\text { 7. Key activities - pri- } \\
\text { mary (2) }\end{array}$ & 3.1 & .77 & & & & & & & 1 & $.58^{* *}$ & .23 & .06 & -.19 \\
\hline $\begin{array}{l}\text { 8. Key activities - sup- } \\
\text { portive (3) }\end{array}$ & 3.28 & .84 & & & & & & & & 1 & .13 & .11 & .12 \\
\hline $\begin{array}{l}\text { 9. Key partnership } \\
\text { (1) }\end{array}$ & 1.25 & .55 & & & & & & & & & 1 & .14 & -.10 \\
\hline $\begin{array}{l}\text { 10. Cost structure } \\
\text { (0) }\end{array}$ & 1.18 & .38 & & & & & & & & & & 1 & .24 \\
\hline 11. Revenue streams (2) & 1.23 & .45 & & & & & & & & & & & 1 \\
\hline
\end{tabular}

Consistency of Strategy

Internal consistency of business strategy was measured also by Cronbach's alpha. It is $\alpha=.643$ which indicates relatively more different and antagonistic relation between specific parameters of the strategy.

Kolgomorov-Smirnov test was used to measure normality of strategy parameters distribution. It was found that most of them do not have a normal distribution and therefore Kendall's tau b was used to measure relationship between specific strategy parameters. In sum we found that majority of them are distinct and have no relationships mutually. Some statements can be expressed about those with significant relationships. At the beginning it would be suitable to stress that the same questions asking about difference were used for strategy and business model too, which means that the strategy parameters were also measured as difference from common business practice in industry.

The correlation matrix of business strategy is too large to graphical publishing, and therefore statistically significant relationships are commented only. Difference from common business industry practice in parameter of vision is related with difference in knowledge about future $(\tau=.41, \mathrm{p}=.01)$. Difference in dynamics and complexity of industry is closely related with industry intensity of competition $(\tau=.39, \mathrm{p}=.017)$ and also in negative relationship with difference in technology $(\tau=.33, \mathrm{p}=.042)$ and clear vision $(\tau=-.4, \mathrm{p}=.042)$.

Difference from common business practice in competition intensity in industry is in strong negative relationship with originality, newness $(\tau=-.59, \mathrm{p}<.0001)$. As expected, difference in knowledge about future is closely related with foresight $(\tau=.56, \mathrm{p}<.0001)$ and competitive advantage and its sustainability is closely related with originality, newness $(\tau=.37$, $\mathrm{p}=.023)$. 
Štefan SLÁVIK, Robert HANÁK. Identification of relation between business model and business strategy and measurement of its tightness

Originality, newness is in positive relationship with technology $(\tau=.45, \mathrm{p}=.005)$. Difference from common business praxis in market position is positively related with comparison with competitors based at difference level $(\tau=.47, \mathrm{p}=.003)$. Market position is also related with originality and uniqueness $(\tau=.31, \mathrm{p}=.04)$ and with sensibility and responsiveness.

Difference in dynamism and speed is negatively related with complexity in industry $(\tau$ $=-.47, \mathrm{p}=.004)$. Originality and uniqueness with market position $(\tau=.31, \mathrm{p}=.04)$ and with sensibility and responsiveness $(\tau=.33, \mathrm{p}=.03)$. Foresight is positively related with sensibility and responsiveness $(\tau=.49, \mathrm{p}=.002)$. Modesty/attack is related with defence/attack $(\tau=.51$, $\mathrm{p}=.001)$. And finally difference from common business praxis in ambition is related with knowledge about future $(\tau=.33, \mathrm{p}=.03)$ and with foresight $(\tau=.49, \mathrm{p}=.02)$.

Consistency of the strategy is well expressed by the number of significant relations $(\mathrm{p} \leq$ 0.05 ) that achieve certain parameters of the strategy. These are the parameters which have four close or at least three more tight connections:

- Dynamics and complexity of the business environment - 4 important connections: competitive conditions, technology, dynamics and speed, clear focus,

- The need (originality, novelty, innovativeness) - 4 important connections: competitive conditions, competitive advantage, technology, market position,

- Originality and uniqueness - 4 important connections: comparison with competitors, market position, foresight, sensitivity and responsiveness.

- The degree of knowledge of the future (originality and foresight) - 3 important connections: the vision, foresight, ambition,

- Comparison with competitors - 3 important connections: technology, market position, originality and uniqueness.

- Foresight - 3 important connections: the rate of knowledge of a future, originality and uniqueness, sensitivity and responsiveness.

- Market position - 3 important connections: the need, originality and uniqueness, sensitivity and awareness.

These parameters identify centres of attraction or cores of strategy, which determine further parameters, and at the same time express the essence of business strategy in the sample of studied companies. All the centrobaric parameters make references to the necessity of quality orientation in the external environment, in-depth knowledge of the environment and original action in this area.

\section{Relation between Business Model and Strategy}

Firstly, a total score of business model was used to measure its relationship with a total score of strategy. This score reflects how a specific company is different according to business model and business strategy in comparison of a common industry practice. So the higher score of business model and business strategy, the larger difference compared with a common business practice of an industry. Correlating total score of business model and total score of strategy it was found that relationship is $r=.265, \mathrm{p}=.042$ only.

To test research assumption that business model affects strategy there were used linear regression with total score of business model as a predictor and total score of strategy as a dependent variable. It was found that score of business model (predicts?) influences upon score of strategy, $\mathrm{F}(1.28)=7.29, \mathrm{p}=.012$ explaining $\mathrm{R}$ squared $=.207$ variance and were standardized $\mathrm{B}=.45, \mathrm{p}=.012$.

Prior to regression analysis, testing was performed whether structure and distribution of the data allow to apply statistical analysis. Several tests and statistical methods were used to identify any possible limitations and none of them was found. Specifically, to avoid bias, data for multicollinearity were tested and tolerance score 1.0 and VIF $=1.0$ were found, therefore it can be concluded that there is no collinearity within research data. Second test was Durbin Watson test, with score 1.56 , which is close to 2 , meaning that independent errors are not in 
Štefan SLÁVIK, Robert HANÁK. Identification of relation between business model and business strategy and measurement of its tightness

OF MANAGEMENT

N THE $21^{\text {st }}$ CENTURY Vol. 12 , No. 1,2017

research data. Checking for bias in residuals by Cook's and Mahalanobis distance did not find any bias. Results reported above lead to conclusion that regression model is valid, fits data well and is based at not biased data.

Secondly, there was tested if business model total score impacts on specific parameters of the strategy. We found that three parameters could be impacted by score of business model only (table 2).

Table 2. Linear regression analysis with total business model score as independent variable.

\begin{tabular}{lclllll}
\hline $\begin{array}{l}\text { Parameters of strategy categories - } \\
\text { dependent variable }\end{array}$ & $\mathbf{b}$ & $\begin{array}{l}\text { Standardized beta coef- } \\
\text { ficient } \beta\end{array}$ & SE $\beta$ & $\mathbf{F}(1,28)$ & P value & $\mathbf{R}^{2}$ \\
\hline $\begin{array}{l}\text { competitive advantage and its sustain- } \\
\text { ability }\end{array}$ & .097 & .406 & .041 & 5.54 & .026 & .165 \\
\hline market position & .151 & .503 & .049 & 9.49 & .005 & .253 \\
\hline originality and uniqueness & .142 & .426 & .057 & 6.2 & .019 & .181 \\
\hline
\end{tabular}

It can be concluded on the base these results that total score of business model does not impact on business strategy except for the competitive advantage and market position. It seems out of data that uniqueness of the business model is reflected especially in the market positon.

\section{Comparing Extreme Groups}

Studied companies compared themselves with direct competitors in the market, if they have the same, similar or different specific business model parameters. Five point Likert scale was used where 1 point means the same value of a parameter as competitors and 5 points mean totally different value. We summed all the parameters of business model and created total score of differences. This score indicates how a particular company is different according to business model in comparison of its competitors. This total score was used to quantify extreme groups which were defined as the lowest quartile and the top quartile of business model quality/ difference. Then we compared by way of independent $t$ - test these two groups in all the parameters of business strategy such as vision, dynamic, etc. to test a presumption that those companies which apply different business model will differ in strategy parameters. We found that they differ in a very limited number of parameters. The most noticeable is market positon: $\mathrm{t}(14)=-1.92, \mathrm{p}=.08, \mathrm{r}=0.42$. We also identified several strategy parameters which have not statistically significant value but they stand out with medium effect size $(r=.03$ or close). They are competitive advantage and its sustainability, originality and uniqueness, passivity - activity. Results are recorded in table 3. 
Table 3. Comparing extreme groups (1st quartile vs 4th quartile in difference from common business practice in industry) for every strategy category.

\begin{tabular}{|c|c|c|c|c|c|c|c|}
\hline Parameters of strategy & $\begin{array}{l}\text { Mean (M) } \\
\text { 1st Quar- } \\
\text { tile }\end{array}$ & $\begin{array}{l}\text { Std. } \\
\text { Devia- } \\
\text { tion 1st } \\
\text { Quartile }\end{array}$ & $\begin{array}{l}\text { Mean (M) } \\
\text { 4th Quar- } \\
\text { tile }\end{array}$ & $\begin{array}{l}\text { Std. } \\
\text { Devia- } \\
\text { tion 4th } \\
\text { Quartile }\end{array}$ & $\mathrm{t}$ & $p$ & $\begin{array}{l}\text { Effect } \\
\text { size } r\end{array}$ \\
\hline Vision, mission, goals & 1.3 & 0.6 & 1.4 & 0.5 & -0.46 & 0.65 & 0.12 \\
\hline $\begin{array}{l}\text { Dynamics and complexity of the busi- } \\
\text { ness environment }\end{array}$ & 3.0 & 1.5 & 3.1 & 0.8 & -0.20 & 0.84 & 0.05 \\
\hline $\begin{array}{l}\text { Competitive conditions in the industry } \\
\text { (competition intensity) }\end{array}$ & 3.4 & 1.0 & 3.1 & 1.2 & 0.56 & 0.59 & 0.15 \\
\hline Level of knowledge of the future & 2.8 & 1.4 & 3.1 & 1.1 & -0.40 & 0.70 & 0.10 \\
\hline $\begin{array}{l}\text { Competitive advantage and its sustain- } \\
\text { ability }\end{array}$ & 2.4 & 0.5 & 3.0 & 1.1 & -1.49 & 0.16 & 0.35 \\
\hline Need (originality, novelty) & 1.7 & 1.0 & 1.8 & 0.9 & -0.13 & 0.90 & 0.03 \\
\hline Technology & 2.1 & 1.1 & 2.4 & 1.4 & -0.49 & 0.63 & 0.13 \\
\hline $\begin{array}{l}\text { Comparison with competitors accord- } \\
\text { ing to rate of difference }\end{array}$ & 2.3 & 0.9 & 3.0 & 0.5 & -1.88 & 0.08 & 0.41 \\
\hline Market position & 3.1 & 1.2 & 4.1 & 1.0 & -1.92 & 0.08 & 0.42 \\
\hline Dynamics and speed & 3.4 & 0.8 & 3.4 & 0.7 & 0.16 & 0.88 & 0.04 \\
\hline Originality and uniqueness & 2.5 & 1.2 & 3.3 & 1.3 & -1.21 & 0.25 & 0.29 \\
\hline Clear focus (clarity, specificity) & 3.8 & 1.2 & 4.3 & 0.7 & -0.89 & 0.39 & 0.23 \\
\hline Foresight & 3.0 & 0.9 & 3.3 & 1.3 & -0.45 & 0.66 & 0.12 \\
\hline Sensitivity and sensibility & 2.6 & 0.7 & 2.9 & 1.5 & -0.43 & 0.67 & 0.11 \\
\hline Ambition & 3.6 & 0.9 & 4.2 & 1.4 & -0.97 & 0.35 & 0.24 \\
\hline Passivity - activity & 3.7 & 0.7 & 3.3 & 0.9 & 1.09 & 0.29 & 0.27 \\
\hline Defence - attack & 3.0 & 1.1 & 3.4 & 1.2 & -0.76 & 0.46 & 0.19 \\
\hline Modesty - courage & 3.3 & 0.7 & 3.3 & 1.0 & 0.00 & 1.00 & 0.00 \\
\hline Coincidence - plan & 3.6 & 1.3 & 4.0 & 0.9 & -0.76 & 0.46 & 0.19 \\
\hline
\end{tabular}

The difference between the most different business models and the least different business model is reflected in the different market position. This means that large differences in a quality of the models have resulted in different market positions. The best quality/ most original model from the minimum quality/little original model differs with better/more original/more different market position. More quality model is likely to result in better market position. Competitive advantage, originality of action and active action can be regarded as some relatively relevant (approximately significant) consequences of difference/ exceptionality of model ascertained by the method of comparing extreme groups.

\section{Discussion}

The aim of the research was to identify the existence and tightness of the relation between the business model and the business strategy. Knowing the existence of this relation and its intrinsic nature will enable managers to penetrate deeper into the unexplored themes of strategic management, and to convert the fit between model and strategy to higher performance 
Štefan SLÁVIK, Robert HANÁK. Identification of relation between business model and business strategy and measurement of its tightness

PROBLEMS

OF MANAGEMENT

IN THE $21^{\text {st }}$ CENTURY Vol. 12, No. 1, 2017

of company and its resilience in a competitive environment. Research of the relation between model and strategy is still taking place only on the basis of conceptual/ theoretical considerations and verbal-qualitative studies. The submitted study is apparently the first attempt (or one of the first attempts) to describe and confirm the relation between model and strategy by way of quantitative methods.

The business model shows a relatively strong consistency because it is a necessary condition for carrying out a business, has got a technical-economic nature and realistic portrayal. The model is more oriented to the internal environment of a company, less succumbs to unpredictable impacts, it is more versatile, has got fewer parameters (blocks), it all appears to increase its consistency. Lager consistency of model can be confirmed by Teece's statements (2010) on logical arrangement of model, Zott and Amit (2010) highlight model as the system of interrelated activities, Benoit and Lecocq (2010) observe the relationships between the different components of a model. Consistency of business strategy is less than the consistency of the model, because it has a virtual rendering, voluntarist nature, it is less to grasp, more complex and individualized as a model and ultimately it has got more parameters than a model. Smaller consistency of the strategy is visible from a wide range of concepts. On the one hand, there are traditionalists who identify a strategy with a plan, e. g. A. A. Thompson, A. J. Strickland, J. E. Gamble (2007) and R. Grant (2008) and, on the other hand, there are structuralists who consider the strategy to be a set of various components, e. g. C. Markides (2008), J. Magretta (2002) and D. C. Hambrick, J. W. Frederickson (2001). The strategy is compiled/conducted in a wide scale from the chaos to the purposefulness, is strongly oriented to the external environment and dependent on external factors, which is likely to reduce its consistency.

Model and strategy show mutual connection in this case if their relation is examined in summary on the base of the total score of their difference. The coefficient of determination is almost $21 \%$ what qualifies the business model as a factor with a significant impact on the strategy, respectively the strategy is to that extent limited by the content and quality of the business model. This finding is not totally in line with the statement by Magretta (2011), which considers the model and strategy as two different things, and is more in line with Masanell Casadesus and Ricart's ideas of their closer ties. Detected dependence explains variability of strategy that is caused by the model, but the remaining extent of variability is sufficient for autonomous, original and perhaps surprising content of strategy. Its determinants may be an object of further research.

If a consequence of the business model to the business strategy is being investigated and strategy is expressed by particular parameters, the impact is indicated in some parameters only. Model relevantly determines or impacts on three parameters of business strategy, which are competitive advantage and its sustainability, market position, originality and uniqueness. This phenomenon can be explained by:

a) Different consistency of model and strategy, the model is more consistent than the strategy, therefore strategy selectively responds to the model.

b) Autonomy, independence, or a small dependence of the model from unforeseeable external influences, that is, a model is more stable than a strategy, and therefore its effect on a strategy reflects in a limited extent.

c) Some features of the model can be translated directly into the strategy, it is especially true for competitive advantage and originality and uniqueness therefore the model has a strategic value/role.

Significant differences between the examined business models based on the base of comparisons of extreme groups were reflected in a single statistically significant and relevant parameters of the strategy, which is the market position. Statistically insignificant, but relevant there are competitive advantage and its sustainability, originality and uniqueness, passivity - activity under method of comparing extreme group. The relevance of market position, competitive advantages and originality/uniqueness were confirmed by regression analysis too. Market position is apparent and well measurable parameter of strategy, which confirms that 
Štefan SLÁVIK, Robert HANÁK. Identification of relation between business model and business strategy and measurement of its tightness

there is a relationship between model and strategy that should be respected. Identification of market position proves that the model and strategy are not entirely independent phenomena, and it is not excluded that further research of a larger sample of companies will confirm an impact of model to the other parameters of strategy that are for now statistically insignificant.

Academic debate is primarily concerned with a topic whether model or strategy is dominant. The relation between them is considered to be self-evident, but unverified. The research has empirically confirmed the existence of a relationship between the model and the strategy that existing research study of Magretta (2011), Newth (2012), Teece (2010), Masanell Casadesus and Ricart (2010, 2011), Muehlhausen (2013), DaSilva and Trkman (2014) describe in the position of presumptions, assumptions, logical reasons, but without empirical verification.

\section{Conclusions}

Quantitative examination of the relations between the business model and business strategy is a pilot research probably even if in a limited sample only, because there were not found similar quantitative studies in the literature. Qualitative presumptions about more closely unspecified relations between models and strategies were confirmed quantitatively in the acceptable range and were proven the concrete implications of the business model to the market position, with less rate of precision some consequences for the competitive advantage, originality/uniqueness of company action and its passivity - activity too. Market position was confirmed by two statistical methods. Identified implications of model to the strategy can be also explained by the different consistency and variability of model and strategy. Knowledge of the scope and content of an impact of the model to the strategy will enable to know the limits of strategy or purposefully to adjust them by modification of the model. Understanding and explanation of the relation between model and strategy will help improve the quality of strategic management of company.

\section{Acknowledgements}

The article is an output of research project VEGA MŠ SR a SAV No. VEGA 1/0019/15 Business models and business strategies of start-ups $(2015-2017)$.

\section{References}

Afuah, A. (2004). Business models. A strategic management approach. McGraw-Hill/Irwin, New York. Collis, D. J., Rukstad, M. G. (2008). Can you say what your strategy is? Harvard Business Review, 86 (4). DaSilva, C. M., Trkman, P. (2014). Business model: What it is and what it is not. Long Range Planning, 47 (6).

Dos Santos, J. F. P., Spector, B., Van der Heyden, L. (2015). Toward a theory of business model change. In: Foss, N. J., Saebi, T. (Eds.), Business model innovation. The organizational dimension. Oxford University Press, Oxford.

Demil, B., Lecocq, X. (2010). Business model evolution: In search of dynamic consistency. Long Range Planning, 43 (2-3).

Grant, R. (2008). Contemporary strategy analysis. Sixth edition, Malden - Oxford - Victoria: Blackwell Publishing.

Hamel, G., Prahalad, C. K. (1996). Competing for the future. Harvard Business School Press.

Hambrick, D. C., Frederickson, J. W. (2001). Are you sure you have a strategy? Academy of Management Executive, 15 (4), 48-59.

Hill, Ch. W. L., Jones, G. R. (2007). Strategic management. An integrated approach. Seventh Edition. Boston - New York: Houghton Miffling Co.

Hunger, T. L., Wheelen, J. D. (2008). Strategic management and business policy. New Jersey: Pearson/ Prentice Hall, Upper Saddle River.

Johnson, M. W., Christensen, C. M., Kagermann, H. (2008). Reinventing your business model. Harvard Business Review, 86 (12), 50-59. 
Štefan SLÁVIK, Robert HANÁK. Identification of relation between business model and business strategy and measurement of its tightness

PROBLEMS

OF MANAGEMENT IN THE $21^{\text {st }}$ CENTURY Vol. 12, No. 1, 2017

68

Karnani, A. (2008). Controversy: The essence of strategy. Business Strategy Review, 19 (4). DOI: 10.1111/j.1467-8616.2008.00560.x.

Keřkovský, M., Vykypěl, O. (2003). Strategické řizení [Strategic management]. Praha: C. H. Beck.

Magretta, J. (2002). Why business model matter? Harvard Business Review, 80 (5), 86-92.

Magretta, J. (2011). Why business models matter. HBR on rebuilding your business model. Harvard Business Review, Press Boston.

Markides, C. (2008). Strategy as balance. Business Strategy Review, 19 (3).

Masanell-Casadesus, R., Ricart, J. E. (2010). From strategy to business models and onto tactics. Long Range Planning, 43 (2-3), 195-215.

Masanell-Casadesus, R., Ricart, J. E. (2011). How to design a winning business model. Harvard Business Review, 89 (1-2), 100-107.

Muehlhausen, J. (2013). Business models for dummies. John Wiley and Sons, Hoboken, New Jersey.

Newth, F. (2012). Business models and strategic management. Business Expert Press, New York.

Osterwalder, A., Pigneur, Y. (2009). Business model generation. Self Published.

Stieglitz, N., Foss, N. J. (2015). Business model innovation. The role of leadership. In: Foss, N. J., Saebi, T. (Eds), Business model innovation. The organizational dimension. Oxford University Press, Oxford.

Teece, D. J. (2010). Business models, business strategy and innovation. Long Range Planning, 43 (2-3). Thompson, A. A. Jr., Strickland III, A. J., Gamble, J. E. (2007). Crafting and executing strategy. Text and readings. 15th edition, Boston - New York: McGraw-Hill/Irwin.

Zott, Ch., Amit, R. (2010) Business model design: An activity perspective. Long Range Planning, 43 (2-3), 2016-226.

Received: April 06, 2017

Accepted: June 20, 2017

$\begin{array}{ll}\text { Štefan Slávik } & \text { PhD. Dipl. Ing., Full Professor, Department of Management, Faculty of Business } \\ & \text { Management, University of Economics in Bratislava, Dolnozemská 1/b, } \\ & \text { Bratislava, Slovakia. } \\ & \text { E-mail: stefan.slavik@euba.sk } \\ & \text { Website: http://fpm.euba.sk } \\ \text { Robert Hanák } & \text { PhD. Mgr. Dipl. Ing., Assistant Professor, Department of Managerial Informatics, } \\ & \text { Faculty of Business Management, University of Economics in Bratislava, } \\ & \text { Dolnozemská 1/b, Bratislava, Slovakia. } \\ & \text { E-mail: robert.hanak@euba.sk } \\ & \text { Website: http://fpm.euba.sk }\end{array}$

